\title{
The Brahman Cattle Performances Through Genetic Improvement Program in Sabah, Malaysia
}

\author{
Abdullah P \\ Department of Veterinary Services and Animal Industry, Kota Kinabalu, Sabah, Malaysia \\ punimin.abdullah@sabah.gov.my
}

\begin{abstract}
A greater understanding of livestock genetics is possible to increase reproductive rate and reduced generation interval of cattle. In Sabah, a genetic improvement program on Brahman cattle was initiated at Livestock Breeding Centre, Tawau using Estimated Breeding Value (EBV) with the collaboration with Australian Brahman Breeders' Association. The objectives of this study were to evaluate the performances of the progeny from the Brahman cattle genetic improvement program in Sabah. There were 120 Brahman cows used in the breeding program. The cows were divided into five herds and each herd was mated with a single pedigree Brahman sire with known EBV. The average body weights of the male calves are heavier than the female calves at all stages of growth. The average weight of the male calves were 179.1; 203.2; and $259.1 \mathrm{~kg}$ and the female calves were 180.1; 197.6; and $246.4 \mathrm{~kg}$ at 200, 400 and 600 day respectively. The average age at first calving is 1290.8 days with ranges from 1190.9 to 1427.0 days. There was no significant different in the age at first calving among the heifers from all the sires. In addition, the time taken for the male calves to reach weight between 300 to $350 \mathrm{~kg}$ is on average 723.7 days and the average weight at that age was on average $316.67 \mathrm{~kg}$. Indeed, the performances of the Brahman cattle using EBV technology in this study had shown big potential to be implemented in wider scale in Malaysia as to increase beef production.
\end{abstract}

Key Words: Brahman Cattle, Genetic Improvement, Body Weight, Age at First Calving, Age at Market Weight

\section{INTRODUCTION}

The livestock industry in Malaysia has grown on average $5.4 \%$ annually for the past decade and in 2010, the industry produced RM 11.26 billion of total ex-farm value of livestock products (Aziz et al. 2011). Although the livestock has indicated positive growth for the past decade, it has not reached its real potential in terms of productivity, value creation and competitiveness. Technical parameters such as breeding performance, growth rate, feed conversion, losses due to diseases and mortalities have not shown much improvement especially in ruminant production. These factors have contributed to low farm efficiency, low farm productivity and higher cost of production and thus portraying unfavorable economic and non-competitive business opportunities to investors.

Majority of the cattle farmers in Malaysia, especially beef cattle farmers, are traditional farmers and kept a small population of cattle. In most situations, inbreeding is the major problem due to inadequate knowledge on cattle breeding. In addition, the availability of good bulls is limited. The practice of artificial insemination in beef cattle production also limited and imported good bull is too expensive for the farmers. Thus, the genetic improvement among the cattle population is very slow.

The development and application of novel and cost effective genetic and reproduction technologies to identify, develop and multiply new line of livestock are aimed at improving product quality and consistency. Through a greater understanding of livestock genetics it is possible to increase reproductive rate and reduce generation interval of cattle. 
An integration of genetic and advanced reproductive technologies could possibly maximize rate of genetic gain.

Rates of genetic change have increased in recent decades in most species in developed countries for several reasons, including more efficient statistical methods for estimating the genetic merit of animals, the wider use of technologies such as artificial insemination and more focused selection on objective traits such as milk yield (Simm et al. 2004). The purpose of animal breeding is not to genetically improve individual animals but to improve animal populations which are to improve future generations of animals. Indeed, presentday progress in livestock performance is largely driven by genetics (Bourdan 2000).

In Sabah, a genetic improvement program on Brahman cattle was initiated and established in 2008. The objective for the breeding program is to produce genetically improves Brahman cattle using Estimated Breeding Value (EBV) with the collaboration with Australian Brahman Breeders' Association. The Brahman's genetic improvement program which produced cattle with EBV based on 200, 400, and 600 day traits was proven feasible (Punimin 2011). The objectives of this study were to evaluate the performances of the progeny from the Brahman cattle genetic improvement program in Sabah.

\section{MATERIAL AND METHODS}

\section{Location}

The study was conducted at Livestock Breeding Centre, Tawau, Sabah, Malaysia $\left(4^{\circ} 17^{\prime} 16.01^{\prime} \mathrm{N}\right.$ and $\left.118^{\circ} 02^{\prime} 26.52 \mathrm{E}\right)$. The farm is located with an elevation of 50 meters above sea level, the average annual rainfall and temperature at the farm is $1,966 \mathrm{~mm}$ and $26.9^{\circ} \mathrm{C}$ respectively.

\section{Cattle management}

The Brahman cattle were reared at a farm with acreage of 366 hectare. The area was divided into 26 paddocks of various sizes depending upon the topography of the farm. The paddocks were planted with either Bracharia decumbens, Panicum maximum var Common, Panicum maximum var Hamill, or Setaria kazungula. The pasture was fertilized every four months with urea, CIRP, and muraite of potash.

There were 120 Brahman cows used in the breeding program. The cows were divided into five herds and each herd was allocated with three or four paddocks depending upon the size of the paddock. Rotational grazing was practiced in the farm. Each herd was mated with a single pedigree Brahman sire with known EBV (Table 1) in two seasonally mating season of 75 days per season at every six months interval. Estimated Breeding Value is a selection index based on accurate unbiased information and will result in more rapid genetic improvement than other approaches (Ashwood 2009). Estimated Breeding Value are accepted as the most appropriate method of estimating genetic merit of an animal for a given trait (Calus 2010). The bull:cow ratio used in the breeding program was 1:25. The animals were weighed every three months. Calves were weaned at $150 \mathrm{~kg}$ or more at the time of weighing. After weaning, the calves were separated and reared in different herd with their own paddocks. Heifers were introduced with the bull upon reaching the weight of $300 \mathrm{~kg}$ or more. 
Table 1. The EBV of the pedigree Brahman bulls used in the breeding program

\begin{tabular}{lccc}
\hline \hline \multirow{2}{*}{ Bull number } & \multicolumn{3}{c}{ Estimated breeding value (EBV) } \\
\cline { 2 - 4 } & 200 day $(\mathrm{kg})$ & 400 day $(\mathrm{kg})$ & 600 day $(\mathrm{kg})$ \\
\hline 5179 & +20 & +31 & +38 \\
5181 & +25 & +39 & +45 \\
5564 & +32 & +47 & +54 \\
5663 & +26 & +29 & +47 \\
5672 & +17 & +31 & +25 \\
\hline
\end{tabular}

Source: Australian Brahman Breeders’ Association

\section{Data collection}

This paper is based on retrospective data on calves born between 2009 and 2011 . There were 200 calves evaluated during that period which comprising 111 male and 89 female.

\section{Statistical analysis}

The association between all dependent and independent variables sex and bull, were examined for statistical difference. A two-way ANOVA was used for body weight, age at first calving and age at market weight data. Any significant difference on these data was tested by least significant difference. IBM SPSS Statistics 21 (SPSS $\left.{ }^{\circledR}\right)$ was used for the evaluation of the fixed effects. The fixed effects that significantly influenced $(\mathrm{P}<0.05)$ all traits were sex, weight at pre-weaning, 200, 400, and 600 day traits, day at first calving and market age.

\section{RESULTS AND DISCUSSION}

\section{Body weight}

The average body weight for male and female calves at pre-weaning, 200, 400, and 600 day is tabulated in Table 1. Generally, the average body weights of the male calves are heavier than the female calves at all stages of growth. The average weight of the male calves were 179.1; 203.2; and $259.1 \mathrm{~kg}$ and the female calves were $180.1 ; 197.6$; and 246.4 $\mathrm{kg}$ at 200, 400, and 600 day respectively. There was a significant effect of sire on body weight at 200 day whereby the male and female calves from sire 5663 were heavier than calves from other sires. At 400 day, the male calves from sire 5664 and female calves from sire 5672 were significantly lighter than the calves from the other sires. There was no significant different in body weight of male calves at 600 day but the female calves from sire 5672 were significantly lighter than the female calves from the other sires. It was expected that calves from sire 5672 were lighter in weight as compared to the calves from other sires as the EBV for 5672 was lower than the rest of the sires being used in the breeding program.

Identification of the genetic merit of livestock is required to make effective decisions about replacing breeding animals and therefore, improving subsequent generations (Golden et al. 2009). The weights of the male and female calves at 200, 400, and 600 day trait produced in the breeding program were higher than Brahman cattle in Malaysia reported by Alsmi \& Wan Zahari (2005) and Nooraisyah (2010). However, when a 
comparison being made to the Brahman cattle produced in developed country, the weights of the Brahman calves in this program were slightly lower than reported by Vargass et al. (2014). The difference in body weight performance between the calves produced in this program and those produced in developed countries is probably due to higher genetic materials used in developed countries as genetic improvement program had been long established. For instance, in United States, the last half century has seen the visual selection process expanded to include quantitative evaluations of merit (Garrick \& Golden 2009).

Table 2. The mean body weight $(\mathrm{kg} \pm \mathrm{SD}(\mathrm{n}))$ at pre-weaning, 200, 400, and 600 day stage according to the sire

\begin{tabular}{|c|c|c|c|c|c|c|c|}
\hline \multirow{2}{*}{$\begin{array}{l}\text { Trait } \\
\text { (day) }\end{array}$} & \multirow{2}{*}{ Sex } & \multicolumn{5}{|c|}{ Pedigree sire number } & \multirow{2}{*}{ Total } \\
\hline & & 5179 & 5181 & 5564 & 5663 & 5672 & \\
\hline \multirow[t]{2}{*}{200} & Male & $\begin{array}{c}143.8 \pm 34.72^{\mathrm{a}} \\
(5)\end{array}$ & $\begin{array}{c}181.3 \pm 20.96^{\mathrm{b}} \\
(26)\end{array}$ & $\begin{array}{c}174.0 \pm 21.40^{\mathrm{a}} \\
(22)\end{array}$ & $\begin{array}{c}189.3 \pm 29.37^{\mathrm{b}} \\
(21)\end{array}$ & $\begin{array}{c}180.1 \pm 29.77^{b} \\
(14)\end{array}$ & $\begin{array}{c}179.1 \pm 26.99 \\
(88)\end{array}$ \\
\hline & Female & $\begin{array}{c}163.5 \pm 10.82^{b} \\
(8)\end{array}$ & $\begin{array}{c}180.3 \pm 19.50^{\mathrm{b}} \\
\quad(24)\end{array}$ & $\begin{array}{c}179.0 \pm 29.16^{\mathrm{b}} \\
(21)\end{array}$ & $\begin{array}{c}195.7 \pm 21.94^{\mathrm{a}} \\
\text { (29) }\end{array}$ & $\begin{array}{c}168.5 \pm 29.45^{\mathrm{b}} \\
(26)\end{array}$ & $\begin{array}{c}180.1 \pm 26.39 \\
(108)\end{array}$ \\
\hline \multirow[t]{2}{*}{400} & Male & $\begin{array}{c}234.0 \pm 15.67^{\mathrm{b}} \\
\text { (5) }\end{array}$ & $\begin{array}{c}205.4 \pm 42.78^{\mathrm{b}} \\
(25)\end{array}$ & $\begin{array}{c}188.3 \pm 27.94^{\mathrm{a}} \\
\text { (22) }\end{array}$ & $\begin{array}{c}216.3 \pm 39.60^{\mathrm{b}} \\
(22)\end{array}$ & $\begin{array}{c}190.9 \pm 20.88^{b} \\
\text { (14) }\end{array}$ & $\begin{array}{c}203.2 \pm 36.45 \\
\quad(88)\end{array}$ \\
\hline & Female & $\begin{array}{c}214.1 \pm 17.39^{\mathrm{a}} \\
\text { (7) }\end{array}$ & $\begin{array}{c}192.5 \pm 41.32^{\mathrm{a}} \\
\text { (24) }\end{array}$ & $\begin{array}{c}198.7 \pm 29.02^{\mathrm{a}} \\
\text { (19) }\end{array}$ & $\begin{array}{c}215.1 \pm 38.00^{\mathrm{a}} \\
(30)\end{array}$ & $\begin{array}{c}176.1 \pm 24.97^{b} \\
(25)\end{array}$ & $\begin{array}{c}197.6 \pm 36.22 \\
(105)\end{array}$ \\
\hline \multirow[t]{2}{*}{600} & Male & $\begin{array}{c}266.0 \pm 52.84 \\
\text { (5) }\end{array}$ & $\begin{array}{c}268.1 \pm 42.85 \\
\quad(22)\end{array}$ & $\begin{array}{c}244.9 \pm 34.50 \\
(18)\end{array}$ & $\begin{array}{c}265.5 \pm 48.59 \\
(20)\end{array}$ & $\begin{array}{c}251.4 \pm 39.26 \\
(14)\end{array}$ & $\begin{array}{c}259.1 \pm 42.69 \\
(79)\end{array}$ \\
\hline & Female & $\begin{array}{c}249.9 \pm 26.57^{\mathrm{a}} \\
(8)\end{array}$ & $\begin{array}{c}246.4 \pm 49.94^{\mathrm{a}} \\
(22)\end{array}$ & $\begin{array}{c}245.3 \pm 46.27^{\mathrm{a}} \\
(19)\end{array}$ & $\begin{array}{c}268.3 \pm 43.04^{\mathrm{ac}} \\
(24)\end{array}$ & $\begin{array}{c}220.5 \pm 27.02^{\mathrm{b}} \\
(24)\end{array}$ & $\begin{array}{c}246.4 \pm 43.86 \\
(101)\end{array}$ \\
\hline
\end{tabular}

${ }^{\mathrm{abc} I n d i c a t e s}$ means within a row with different letters are significantly different $(\mathrm{P}<0.05)$

\section{Age at first calving}

The average age at first calving is 1290.8 days with ranges from 1190.9 to 1427.0 days (Table 3). There was no significant different in the age at first calving among the heifers from all the sires. However, heifers sired by 5564 have relatively shorter age at first calving (1190.9 days). The average age at first calving recorded is still very long. In Australia, the age at first calving for the Brahman cattle was ranging from 724 to 805 days (Abba). The big difference could be due to environment and management factors. Boligon et al. (2010) reported in their study that the large influence of non-additive genetic effects and environmental factors on age at first calving indicates that the expression of this trait depends on adequate management conditions.

Table 3. The age at first calving (days $\pm \mathrm{SD}(\mathrm{n})$ ) for the heifer

\begin{tabular}{lc}
\hline \hline Pedigree sire number & Age of first calving (days) \\
\hline 5179 & $1427.0 \pm 253.88(6)$ \\
5181 & $1251.7 \pm 189.58(18)$ \\
5564 & $1190.9 \pm 164.37(20)$ \\
5663 & $1263.9 \pm 164.37(20)$ \\
5672 & $1381.4 \pm 239.82(19)$ \\
\hline Average & $1290.8 \pm 211.94(83)$ \\
\hline
\end{tabular}




\section{Age at market weight}

In Malaysia, the market weight for beef cattle is between 300 and $350 \mathrm{~kg}$. The common breeds of cattle reared by farmers were Kedah-Kelantan and Brakmas, and these breeds reached the body weight less than $275 \mathrm{~kg}$ at 30 months of age (Alsmi \& Wan Zahari 2005). Therefore, most of the cattle sold were more than 30 months of age.

In this study, the time taken for the male calves to reach weight between 300 to $350 \mathrm{~kg}$ is on average 723.7 days and the average weight at that age was on average $316.67 \mathrm{~kg}$ (Table 4). The male calves sired by 5179, 5181, and 5663 have significantly reached the market weight faster than male calves sired by 5564 and 5672. The growth performance for the male calves to reach the market weight was much faster and with shortened rearing period. Shorten rearing period will benefits the farmers whereby the cost of production could be reduced.

Table 4. The age (days $\pm \mathrm{SD}(\mathrm{n})$ ) to reached weight between $300-350 \mathrm{~kg}$ for the bull

\begin{tabular}{lcc}
\hline \hline Pedigree sire number & Age (days) & Weight $(\mathrm{kg})$ \\
\hline 5179 & $720.0 \pm 203.36^{\mathrm{a}}(4)$ & $306.5 \pm 3.42(4)$ \\
5181 & $667.1 \pm 143.39^{\mathrm{a}}(17)$ & $317.3 \pm 11.27(17)$ \\
5564 & $779.5 \pm 69.63^{\mathrm{b}}(12)$ & $314.8 \pm 15.08(12)$ \\
5663 & $706.8 \pm 107.65^{\mathrm{a}}(14)$ & $318.4 \pm 8.92(14)$ \\
5672 & $765.6 \pm 81.04^{\mathrm{b}}(13)$ & $318.5 \pm 13.54(13)$ \\
\hline Average & $723.7 \pm 120.35(60)$ & $316.67 \pm 11.89(60)$ \\
\hline
\end{tabular}

${ }^{\text {ab }}$ Indicates means within a column with different letters are significantly different $(\mathrm{P}<0.05)$

The use of economic traits of importance as a selection criterion may promote desirable correlated response in growth and could contribute to increased profitability in the production enterprise (Kahi et al. 2007). The majority of national genetic improvement programs for beef cattle have emphasized selection to improve outputs, such as body weight and more recently, fertility and carcass traits (Herd et al. 2003). This study had shown that the body weight of the calves based on the three traits was higher compared to previous reports. The age of market weight was reduced and the reduction of the age at market weight will definitely benefits the farmers. Generally in Malaysia, cattle performances are low due to the lack of selection criterion imposed by farmers. There is evidence that there is much room for improvement by raising performance, in areas where it is now low. The age of first calving probably could be reduced as to increase the heifer fertility. There is a need to also consider avenues for reducing inputs in order to improve efficiency of production and to increase profit (Herd et al. 2003). Genetic improvement program in Brahman cattle using EBV technology had shown some prospect in increasing cattle productivity. Rates of genetic change have increased in recent decades in most species in developed countries for several reasons, including more efficient statistical methods for estimating the genetic merit of animals, the wider use of technologies such as artificial insemination and more focused selection on objective traits such as milk yield (Simm et al. 2004). The prospects for increasing output per unit of input are good both from the application of already proven technologies to a larger proportion of the world's animal populations, and from the development of new technologies (Kahi et al. 2007). 


\section{CONCLUSION}

Genetic improvement program in Brahman cattle production using EBV technology as the selection index had shown some prospect in increasing cattle productivity. The magnitude of genetic parameters estimated for body weight, age at first calving, and age at market weight in this study indicates that selection within the Brahman cattle had improved the body weight and age at market weight but not the age at first calving. Further research need to be done on the age of first calving as the presence data show that it was too long. Indeed, the performances of the Brahman cattle using EBV technology in this study had shown big potential to be implemented in wider scale in Malaysia as to increase beef production, to reduce the cost of production and to increase farm efficiency in beef production.

\section{REFERENCES}

Alsmi SZ, Wan Zahari M. 2005. Beef production for Malaysian enterpreneurs. Selangor (Malaysia): Malaysian Agricultural Research and Development Institute (MARDI).

Ashwood A. 2009. Basic genetics. [Internet]. [cited 29 March 2016]. Available from: http://brahman.com.au/technical_information/selection/BasicGenetics.html

Aziz AJ, Abu Hassan MA, Mokhdzir L. 2011. Revitalising the livestock industry through technology transfer. In: Yaakub H, Engku Azahan EA, Wahid H, Ganabadi S, Sukardi S, Sumita S, Loh TC, Panandam JM, Jasmi Y, Wan Khadijah WE, Jelan ZA, editors. Revitalising the Livestock Industry Through Technology Transfer. Proceeding of the Malaysian Society of Animal Production 32 ${ }^{\text {nd }}$ Annual Conference. Tawau, 6-9 June 2011. Selangor (Malaysia): Malaysian Society of Animal Production. p. 1-3.

Boligon AA, de Albuquerque LG, Mercadante MEZ, Lôbo RB. 2010. Study of relations among age at first calving, average weight gains and weights from weaning to maturity in Nellore cattle. Revista Brasileira de Zootecnia. 39:746-751.

Bourdan, RM. 2000. Understanding animal breeding. $2^{\text {nd }}$ Ed. NewJersey (US): Prentice-Hall Inc.

Calus MPL. 2010. Genomic breeding value prediction: Methods and procedures. Animal 4:157164.

Garrick DJ, Golden BL. 2009. Producing and using genetic evaluation in the United States beef industry of today. J Anim Sci. 87:E11-E18.

Golden BL, Garrick DJ, Benyshek LL. 2009. Milestones in beef cattle genetic evaluation. J Anim Sci. 87:E3-E10.

Herd RM, Archer JA and Arthur PF. 2003. Reducing the cost of beef production through genetic improvement in residual feed intake: Opportunity and challenges to application. J Anim Sci. Suppl.1:E9-E17.

Kahi AK, Oguni T, Sumio Y, Hirooka H. 2007. Genetic relationship between growth and carcass traits and profitability in Japanese Brown cattle. J Anim Sci. 85:348-355.

Nooraisyah S. 2010. The impact on performance traits of calf sired by stud Brahman bull [Dissertation]. [Kota Kinabalu (Malaysia)]: Universiti Malaysia Sabah.

Punimin A. 2011. Genetic improvement in Brahman cattle using Estimated Breeding Value (EBV). In: Yaakub H, Engku Azahan EA, Wahid H, Ganabadi S, Sukardi S, Sumita S, Loh TC, Panandam JM, Jasmi Y, Wan Khadijah WE, Jelan ZA, editors. Revitalising the Livestock Industry Through Technology Transfer. Proceeding of the Malaysian Society of Animal Production 32 ${ }^{\text {nd }}$ Annual Conference. Tawau, 6-9 June 2011. Selangor (Malaysia): Malaysian Society of Animal Production. p. 29-30. 
Simm G, Bunger L, Villanueva B, Hill WG. 2004. Limits to yield of farm species: Genetic improvement of livestock. In: Sylvester-Bradley R, Wiseman J, editors. Yields of farmed species: Constraints and opportunities in the $21^{\text {st }}$ century. Nottingham (UK): Nottingham University Press. p. 123-141.

Vargas G, Buzanskas ME, Guidolin DGF, Grossi DA, Bonifacio AS, Lobo RB, Fonseca R, Oliveira JA, Munari DP. 2014. Genetic parameter estimation for pre- and post-weaning traits in Brahman cattle in Brazil. Trop Anim Health Prod. 46:1271-1278. 